\title{
Effects of Potassium, Calcium, and Magnesium Ratios in Soil on Their Uptake and Fruit Quality of Pummelo
}

\author{
Hien Huu Nguyen ${ }^{1}$, Somsak Maneepong ${ }^{2} \&$ Potjaman Suraninpong ${ }^{2}$ \\ ${ }^{1}$ Faculty of Agriculture, Forestry and Fisheries, Vinh University, Nghe An, Vietnam \\ ${ }^{2}$ School of Agricultural Technology, Walailak University, Nakhon Si Thammarat, Thailand \\ Correspondence: Hien Huu Nguyen, Faculty of Agriculture, Forestry and Fisheries, Vinh University, Nghe An, \\ Vietnam. E-mail: huuhiendhv@gmail.com
}

Received: September 26, 2017

Accepted: October 22, 2017

Online Published: November 15, 2017

doi:10.5539/jas.v9n12p110

URL: https://doi.org/10.5539/jas.v9n12p110

The research is financed by Thailand Research Fund and Walailak University.

\begin{abstract}
Potassium (K), Calcium (Ca), and Magnesium ( $\mathrm{Mg}$ ) are essential nutrients for pummelo. These nutrients are strongly antagonistic to each other. In case of excess concentration of one element, the uptake of the other elements is inhibited. This study was conducted on 17-year-old pummelo (Citrus maxima Merr.) during production year 2013 to 2015 to examine the effects of $\mathrm{K}, \mathrm{Ca}$, and $\mathrm{Mg}$ in soil on their uptake and fruit quality. The experiment was performed using six treatments with five replications. $\left(\mathrm{NH}_{4}\right)_{2} \mathrm{SO}_{4}, \mathrm{KCl}, \mathrm{CaSO}_{4} \cdot 2 \mathrm{H}_{2} \mathrm{O}$, and $\mathrm{ZnSO}_{4} \cdot 7 \mathrm{H}_{2} \mathrm{O}$ were applied on top of farmer practice for the T1. $\left(\mathrm{NH}_{4}\right)_{2} \mathrm{SO}_{4}$ was omitted for the $\mathrm{T} 2$, $\mathrm{KCl}$ was omitted for the T3, $\mathrm{CaSO}_{4} \cdot 2 \mathrm{H}_{2} \mathrm{O}$ was omitted for the T4, no additional fertilizers were applied for the $\mathrm{T} 5$ (farmer practice), $\left(\mathrm{NH}_{4}\right)_{2} \mathrm{SO}_{4}$ and $\mathrm{CaSO}_{4} \cdot 2 \mathrm{H}_{2} \mathrm{O}$ were omitted for the T6, but $5 \mathrm{Ca}\left(\mathrm{NO}_{3}\right)_{2} \cdot \mathrm{NH}_{4} \mathrm{NO}_{3} \cdot 10 \mathrm{H}_{2} \mathrm{O}$ were applied instead. The soil $\mathrm{pH}$ was neutral and salinity was slight. Exchangeable $\mathrm{K}, \mathrm{Ca}$ and $\mathrm{Mg}$ were higher than their optimum ranges. The extractable $\mathrm{Zn}$ in the soil and $\mathrm{Zn}$ in the leaves were lower than their optimum ranges. However, the problem can be solved by a single application $250 \mathrm{~g}$ tree ${ }^{-1}$ of $\mathrm{ZnSO}_{4} \cdot 7 \mathrm{H}_{2} \mathrm{O}$. Pummelo cannot uptake $\mathrm{K}$ to a sufficient level, even though it is abundant in the soil. High exchangeable $\mathrm{Na}$ and low $\mathrm{K} / \mathrm{Mg}$ mole ratio in soil inhibited $\mathrm{K}$ uptake. Concentration of $\mathrm{Ca}$ in leaves corresponded to $\mathrm{Ca}$ and $\mathrm{Ca} / \mathrm{Mg}$ mole ratio in the soil. Concentrations of $\mathrm{Mg}$ and $\mathrm{K}$ in leaves negatively correlated with each other. High $\mathrm{Mg}$ and $\mathrm{Na}$ in the soil inhibited the uptake of $\mathrm{K}$ and $\mathrm{Ca}$, thereby causing extravagant consumptions of $\mathrm{Mg}$. The fruit qualities were better in the treatment which mole ratios of $\mathrm{K} / \mathrm{Ca}, \mathrm{K} / \mathrm{Mg}$ and $\mathrm{Ca} / \mathrm{Mg}$ were 0.24 to $0.44,0.31$ to 0.44 and 0.89 to 1.29 , respectively. Juice ratio of the pummelo positively correlated with the edible portion and negatively correlated with peel thickness.
\end{abstract}

Keywords: fruit quality, plant nutrition, pummelo, nutrient uptake, nutrient ratio

\section{Introduction}

Pummelo (Citrus maxima Merr.) is a plant with vigorous growth and high yield, which requires a large amount of nutrients. According to Maneepong (2009), the quantities of N, P, K, Ca, Mg required for fruit production were $1.72,0.25,3.00,1.51,0.23 \mathrm{~g} /$ fruit, respectively. Nutrient concentrations in pummelo growing soil decline rapidly. Nutrient supplements are important for maintaining nutrient concentration and balance. Improper maintenance will effect fruit quality such as sweetness and peel thickness, and glutinous texture in severe cases. $\mathrm{K}, \mathrm{Ca}$ and $\mathrm{Mg}$ uptake do not depend only on their concentrations in the soil, but also on their ratios. An excess application of one nutrient may induce deficiency of the others. $\mathrm{K}, \mathrm{Ca}$ and $\mathrm{Mg}$ strongly interfere with each other during the uptake process (Voogt, 1987). High Mg concentration in soil inhibits the uptake of K and Ca (Nguyen, Maneepong, \& Suraninpong, 2015), whereas high K concentration in nutrient solution inhibits the uptake of Ca and Mg (Jones, 1999; Voogt, 1987; Nukaya, Goto, Jang, Kano, \& Ohkawa, 1995; Bar-Tal \& Pressman, 1996). $\mathrm{Mg}$ deficiency may occur when the soil has high Ca:Mg ratio (Bergmann, 1992). Increasing K concentration in the nutrient solution increased the incidence of $\mathrm{Ca}$ deficiency of tomato. Occurrence of the Ca deficiency correlated to K:Ca ratio in tomato leaves (Bar-Tal \& Pressman, 1996). Increasing the Mg concentration in low Ca nutrient solution increased the Ca deficiency of tomato (Hao \& Papadopoulos, 2003). Pummelo can be grown 
on non-saline upland soil and slight saline soil. Its growth rate is retarded on saline soil, but the fruit test is more favourable by consumers.

The objective of this study was to evaluate the effects of $\mathrm{K}, \mathrm{Ca}$ and $\mathrm{Mg}$ ratios on nutrient uptake and fruit quality of pummelo growing on salt marsh soil.

\section{Materials and Methods}

\subsection{Experimental Design}

A representative pummelo orchard in Pakpanang district, Nakhon Si Thammarat Province, Thailand (latitude $8^{\circ} 31^{\prime} 07^{\prime \prime} \mathrm{N}$, longitude $100^{\circ} 12^{\prime} 55^{\prime \prime} \mathrm{E}$ ) was selected. Most of the pummelo trees were planted in 1997, but some of them were re-planted later. Only Tuptim Siam variety was grown on this orchard. The pummelo was grown in blocks of land. Each block was separated by a furrow of $8.8 \mathrm{~m}$ wide and $1.5 \mathrm{~m}$ deep. Thirty trees were arranged in double rows in each block. Spacing between two adjacent trees was $5.3 \mathrm{~m}$, and between rows was $5.2 \mathrm{~m}$. Five trees from each block with a similar canopy volume and equal age were selected for placing into each treatment (Table 1). Ammonium sulfate, potassium chloride, calcium sulfate and zinc sulfate were applied on top of farmer practice for treatment 1 (T1). Ammonium sulfate was omitted for treatment 2 (T2). Potassium chloride was omitted for treatment 3 (T3). Calcium sulfate was omitted for treatment 4 (T4). No additional fertilizers were applied for treatment 5 (T5). Potassium chloride and Calcium ammonium nitrate were applied for the treatment 6 (T6). The study was performed during June 2013 to March 2015.

Table 1. Fertilizer rates in a year for each treatment. Application of $\left(\mathrm{NH}_{4}\right)_{2} \mathrm{SO}_{4}$ and $5 \mathrm{Ca}\left(\mathrm{NO}_{3}\right)_{2} \cdot \mathrm{NH}_{4} \mathrm{NO}_{3} \cdot 10 \mathrm{H}_{2} \mathrm{O}$ were splitted equally 4 times a year, $\mathrm{KCl}$ twice a year, and $\mathrm{CaSO}_{4} \cdot 2 \mathrm{H}_{2} \mathrm{O}$ and $\mathrm{ZnSO}_{4} \cdot 7 \mathrm{H}_{2} \mathrm{O}$ once a year. The first application was performed in June 2013

\begin{tabular}{llllll}
\hline Treatment & $\left(\mathrm{NH}_{4}\right)_{2} \mathrm{SO}_{4}$ & $\mathrm{KCl}$ & $\mathrm{CaSO} \cdot 2 \mathrm{H}_{2} \mathrm{O}$ & $5 \mathrm{Ca}\left(\mathrm{NO}_{3}\right)_{2} \cdot \mathrm{NH}_{4} \mathrm{NO}_{3} \cdot 10 \mathrm{H}_{2} \mathrm{O}$ & $\mathrm{ZnSO}_{4} \cdot 7 \mathrm{H}_{2} \mathrm{O}$ \\
\hline T1 (All) & $4 \mathrm{~kg}$ & $2 \mathrm{~kg}$ & $5 \mathrm{~kg}$ & 0 & $250 \mathrm{~g}$ \\
T2 (-N) & 0 & $2 \mathrm{~kg}$ & $5 \mathrm{~kg}$ & 0 & $250 \mathrm{~g}$ \\
T3 (-K) & $4 \mathrm{~kg}$ & 0 & $5 \mathrm{~kg}$ & 0 & $250 \mathrm{~g}$ \\
T4 (-Ca) & $4 \mathrm{~kg}$ & $2 \mathrm{~kg}$ & 0 & 0 & $250 \mathrm{~g}$ \\
T5 (Farmer practice) & 0 & 0 & 0 & 0 & 0 \\
T6 (All:15-0-0) & 0 & $2 \mathrm{~kg}$ & 0 & $5.6 \mathrm{~kg}$ & $250 \mathrm{~g}$ \\
\hline
\end{tabular}

Note. Fertilizers were not applied for treatment T5 by the authors, but the farmer applied NPK and sprayed KCl.

\subsection{Soil Sampling and Analysis}

Soil samples were taken twice, before treatment application and one year after treatment application. The samples were taken from 4 different positions directly beneath the outer canopy of each tree between 0 to $20 \mathrm{~cm}$ depth by a sampling tube. The samples were mixed, air-dried, ground and gravel and debris were removed by sieving through a $2 \mathrm{~mm}$ screen. Soil $\mathrm{pH}$ was measured using 1:2.5 soil:water ratio. Electrical conductivity was measured using 1:5 siol:water ratio and the value was multiplied by 6 to obtain electrical conductivity at saturation (ECe) (Shaw, 1999). Available $\mathrm{P}$ was extracted with $0.03 \mathrm{M} \mathrm{NH} 4 \mathrm{~F}$ in $0.10 \mathrm{M} \mathrm{HCl}$ (Bray II solution), and its concentration was analyzed using the molybdenum blue method. Exchangeable $\mathrm{K}, \mathrm{Ca}$ and $\mathrm{Mg}$ were extracted with $1 \mathrm{M} \mathrm{NH}_{4} \mathrm{OAc}$ at $\mathrm{pH}$ 7.0. Concentration of $\mathrm{K}$ was analyzed by a flame photometer. Concentrations of $\mathrm{Ca}$ and $\mathrm{Mg}$ were analyzed by an atomic absorption spectrophotometer (AAS). $\mathrm{Zn}$ was extracted with $0.05 \mathrm{M}$ di-ethylene tri-amine pentaacetic acid in $0.01 \mathrm{M}$ tri-ethanolamine and $0.05 \mathrm{M} \mathrm{CaCl}_{2}$ (DTPA solution), and its concentration was analyzed by an AAS (Jones, 2001, 2003).

\subsection{Leaf Sampling and Analysis}

Pummelo leaves were sampled five times (June and November, 2013; June and October, 2014; and January, 2015). The leaves were sampled from the third or fourth position, 3 to 5 months old, newly flush, and non-fruiting twig on the outer canopy. The samples were dried at $65{ }^{\circ} \mathrm{C}$, ground, and passed through a $1 \mathrm{~mm}$ sieve. $\mathrm{N}$ was analyzed by the Kjeldahl method. The samples were digested with 2:1 $\mathrm{HNO}_{3}: \mathrm{HClO}_{4}$ for $\mathrm{K}, \mathrm{Ca}, \mathrm{Mg}$ and $\mathrm{Zn}$ analysis. Concentration of $\mathrm{K}$ was analyzed by a flame photometer. Concentrations of $\mathrm{Ca}, \mathrm{Mg}$ and $\mathrm{Zn}$ were analyzed by an AAS (Soil and Plant Analysis Council, 1998). 


\subsection{Fruit Sampling and Analysis}

Pummelo fruits were sampled twice, on March 2014 and February 2015. A medium size of fully ripen pummelo fruit was sampled from each replication (one fruit from each tree). Fruit weight and endocarp (pulp) weight were determined, and the edible portion was calculated from their ratios. Thickness of flavedo and albedo (peel) was measured at four points equatorially using a ruller. The pummelo juice was extracted by a blander, and the juice ratio was calculated from juice volume and fruit weight. Total soluble solid (TSS) was determined using a hand refractometer. Titratable acidity (TA) was determined by titration of $50 \mathrm{ml}$ juice with $0.1 \mathrm{M} \mathrm{NaOH}$ and calculated by assuming that all acids in the juice are equivalent to citric acid (Boland, 1995). The test index (TSS/TA) was calculated from the ratio of TSS and TA.

\subsection{Analysis of Experimental Data}

The data were subjected to analysis of variance (ANOVA) in a completely randomized biock design that contained six treatments and five replicates per treatment. The mean separation was performed by Duncan's multiple range tests at the $5 \%$ level of significance.

\section{Results and Discussion}

\subsection{Effects of Treatments on Soil Properties}

Soil of this orchard was derived from marine sediment. Therefore, concentrations of $\mathrm{K}, \mathrm{Ca}$ and $\mathrm{Mg}$ were high, and $\mathrm{pH}$ value was close to neutral. No significant differences were found in soil $\mathrm{pH}$ among treatments before application of the different fertilizers (Table 2). However, $\mathrm{pH}$ tended to decrease after their application except on T6. The $\mathrm{pH}$ from $\mathrm{T} 6$ was significantly higher than those from $\mathrm{T} 1$ and T4. Increasing soil $\mathrm{pH}$ of the $\mathrm{T} 6$ may due to application of calcium ammonium nitrate (15-0-0). The optimum $\mathrm{pH}$ range for pummelo growing soil was suggested to be 5.5 to 6.5 (Maneepong, 2008), which is lower than the pH range of the soil in this study.

Soil ECe did not significantly differ among treatments at the beginning of experiment, but it significantly differed after treatments (Table 2). The ECe tended to increase, except on T2 (no additional $\left(\mathrm{NH}_{4}\right)_{2} \mathrm{SO}_{4}$ ). Slightly saline soil is recommended for pummelo growing $(2.0$ to $3.0 \mathrm{mS} / \mathrm{cm})$, although the soil tends to retard growth rate, but better fruit quality will be obtained (Maneepong, 2008; Samarankoon, Weerasinghe, \& Weerakkody, 2006). A large over recommended range was found in T1 and T3; this may be caused by a large amount of fertilizer application (Tables 1 and 2).

The available $\mathrm{P}$ of the soil was found to be very high in all treatments due to its nature, although phosphorus fertilizer was not applied (Table 2). The optimum range was suggested only 15 to $25 \mathrm{mg} / \mathrm{kg}$ (Maneepong, 2008), therefore pummelo in this orchard should not require additional $\mathrm{P}$ fertilizer.

Exchangeable $\mathrm{K}$ varied in a wide range between treatments both before and after the treatment application (Table 2). Pummelo trees were grown on raise beds and $\mathrm{K}$ fertilizer is frequently applied by a farmer, therefore the soil $\mathrm{K}$ was not homogeneously distributed. Application of $\left(\mathrm{NH}_{4}\right)_{2} \mathrm{SO}_{4}$ and $\mathrm{KCl}$ at the same time did not increase $\mathrm{K}$ concentrations in the soils ( $\mathrm{T} 1$ and $\mathrm{T} 4$ ), whereas application of $\mathrm{KCl}$ alone increased the $\mathrm{K}$ concentration (T2). This may due to leaching and surface erosion during the flooding period. The optimum range recommended was only 100 to $150 \mathrm{mg} / \mathrm{kg}$ (Maneepong, 2008), which was lower than $\mathrm{K}$ in the soils both before and after the treatment application.

Exchangeable $\mathrm{Ca}$ varied in a wide range similar to that of $\mathrm{K}$. The highest value was found on $\mathrm{T} 3$, which was significantly higher than that of T5 (farmer practice) both before and after treatment application (Table 2). $\mathrm{CaSO}_{4} \cdot 2 \mathrm{H}_{2} \mathrm{O}$ was applied to T1, T2 and T3. However, Ca tended to decline after the application. The change may occur due to surface erosion, similar to the case of K. A large increase was found in T6, which calcium ammonium nitrate was applied. The exchangeable $\mathrm{Ca}$ of all plots was higher than $2,000 \mathrm{mg} / \mathrm{kg}$ both before and after the treatment application, whereas the optimum range recommended was $1,000 \mathrm{mg} / \mathrm{kg}$ to $2,000 \mathrm{mg} / \mathrm{kg}$ (Maneepong, 2008). Zamaniyan et al. (2012) found that the K uptake by chicory cultured in nutrient solution depends on $\mathrm{K} / \mathrm{Ca}$ ratio. Increasing the $\mathrm{K} / \mathrm{Ca}$ ratio also increased $\mathrm{K}$ concentrations both in leaves and root. If the $\mathrm{K} / \mathrm{Ca}$ ratio was higher than $6 / 4$, the yield decreased and caused morphological damage related to Ca deficiency, such as pith hole and tip burn.

Exchangeable Mg presented in the same order of $\mathrm{K}$ for T1, T2 and T3, but it tended to be higher for T4, T5 and T6 (Table 2). Mg was not applied, because the native concentration is much higher than the suggested optimum range (120 mg/kg to $240 \mathrm{mg} / \mathrm{kg}$; Maneepong, 2008). High Mg concentration either in soil or plant often causes poor K status in plant (Kirkby \& Mengel, 1976). 
Exchangeable Na of T4, T5 and T6 was significantly higher than T1, T2 and T3 both before and after the treatment application (Table 2). An average of $45 \%$ of the Na was removed from the soil after the application. The result showed that the $\mathrm{Na}$ is loosly retained by soil. $\mathrm{Na}$ is not an escential nutrient element, but it affects the uptake of other cations. A negative correlation between soil salinity and uptake of $\mathrm{P}, \mathrm{K}, \mathrm{Ca}, \mathrm{Cu}, \mathrm{Fe}$ and $\mathrm{Mn}$ by maize and positive correlation with Na was observed (Hassan, Derwy, Mudren, Knadsin, \& Olseon, 1970).

$\mathrm{Zn}$ deficiency symptom was found in this area according to our previous study. Therefore, $\mathrm{ZnSO}_{4} \cdot 7 \mathrm{H}_{2} \mathrm{O}$ was applied to all treatments except T5 (farmer practice). No significant difference in the $\mathrm{Zn}$ concentrations were found among treatments before application (Table 2). After $\mathrm{Zn}$ application, the concentrations increased above its optimum range $(1.1 \mathrm{mg} / \mathrm{kg}$ to $3.0 \mathrm{mg} / \mathrm{kg}$; Maneepong, 2008) except T6, whereas that of the T5 was still lower than the range.

Table 2. Chemical properties of top-soils $(0$ to $20 \mathrm{~cm})$ before and after treatment application

\begin{tabular}{|c|c|c|c|c|c|c|c|}
\hline \multirow{2}{*}{ Chemical properties } & \multirow{2}{*}{ Sampling times } & \multicolumn{6}{|c|}{ Treatments } \\
\hline & & $\mathrm{T} 1$ & $\mathrm{~T} 2$ & $\mathrm{~T} 3$ & $\mathrm{~T} 4$ & $\mathrm{~T} 5$ & T6 \\
\hline \multirow[t]{2}{*}{$\mathrm{pH}$} & Before & $7.2 \pm 0.2 \mathrm{a}$ & $7.1 \pm 0.1 \mathrm{a}$ & $7.1 \pm 0.5 \mathrm{a}$ & $6.9 \pm 0.3 \mathrm{a}$ & $7.1 \pm 0.3 \mathrm{a}$ & $7.1 \pm 0.1 \mathrm{a}$ \\
\hline & After & $6.6 \pm 0.3 \mathrm{~b}$ & $6.8 \pm 0.4 \mathrm{ab}$ & $7.0 \pm 0.3 \mathrm{ab}$ & $6.7 \pm 0.3 \mathrm{~b}$ & $6.8 \pm 0.7 \mathrm{ab}$ & $7.3 \pm 0.1 \mathrm{a}$ \\
\hline \multirow[t]{2}{*}{$\mathrm{ECe}(\mathrm{mS} / \mathrm{cm})$} & Before & $2.4 \pm 0.3 \mathrm{a}$ & $3.4 \pm 1.6 \mathrm{a}$ & $2.2 \pm 0.9 \mathrm{a}$ & $3.1 \pm 0.9 \mathrm{a}$ & $2.8 \pm 0.2 \mathrm{a}$ & $2.6 \pm 1.0 \mathrm{a}$ \\
\hline & After & $3.5 \pm 0.7 \mathrm{ab}$ & $2.1 \pm 0.7 \mathrm{c}$ & $4.7 \pm 1.8 \mathrm{a}$ & $3.1 \pm 0.3 \mathrm{bc}$ & $3.1 \pm 0.4 \mathrm{bc}$ & $2.8 \pm 0.3 b c$ \\
\hline \multirow[t]{2}{*}{ Avai. P (mg/kg) } & Before & $185 \pm 30 \mathrm{ab}$ & $190 \pm 114 \mathrm{ab}$ & $279 \pm 93 a$ & $201 \pm 132 \mathrm{ab}$ & $107 \pm 27 b$ & $103 \pm 40 b$ \\
\hline & After & $262 \pm 65 \mathrm{ab}$ & $308 \pm 74 a$ & $301 \pm 71 \mathrm{a}$ & $206 \pm 67 b$ & $208 \pm 96 b$ & $162 \pm 21 b$ \\
\hline \multirow[t]{2}{*}{ Exch. K (mg/kg) } & Before & $1402 \pm 475 a$ & $975 \pm 407 \mathrm{ab}$ & $1172 \pm 95 \mathrm{ab}$ & $975 \pm 587 \mathrm{ab}$ & $628 \pm 270 b$ & $924 \pm 296 \mathrm{ab}$ \\
\hline & After & $1062 \pm 242 \mathrm{ab}$ & $1149 \pm 255 \mathrm{a}$ & $827 \pm 240 \mathrm{ab}$ & $879 \pm 167 \mathrm{ab}$ & $944 \pm 302 \mathrm{ab}$ & $773 \pm 150 b$ \\
\hline \multirow[t]{2}{*}{ Exch. Ca (mg/kg) } & Before & $3207 \pm 466 \mathrm{ab}$ & $3752 \pm 1124 \mathrm{ab}$ & $4179 \pm 1791 \mathrm{a}$ & $3305 \pm 293 \mathrm{ab}$ & $2487 \pm 689 b$ & $2412 \pm 418 b$ \\
\hline & After & $2963 \pm 260 b$ & $3433 \pm 1144 \mathrm{ab}$ & $4146 \pm 727 a$ & $2821 \pm 99 b$ & $2544 \pm 745 b$ & $3363 \pm 402 \mathrm{ab}$ \\
\hline \multirow[t]{2}{*}{ Exch. $\mathrm{Mg}(\mathrm{mg} / \mathrm{kg})$} & Before & $1465 \pm 72 b c$ & $1482 \pm 29 b c$ & $1378 \pm 189 \mathrm{c}$ & $1564 \pm 162 b$ & $1768 \pm 31 \mathrm{a}$ & $1751 \pm 105 a$ \\
\hline & After & $1520 \pm 146 b$ & $1185 \pm 148 \mathrm{c}$ & $1227 \pm 181 \mathrm{c}$ & $1641 \pm 120 \mathrm{a}$ & $1742 \pm 128 \mathrm{a}$ & $1595 \pm 139 a b$ \\
\hline \multirow[t]{2}{*}{ Exch. $\mathrm{Na}(\mathrm{mg} / \mathrm{kg})$} & Before & $490 \pm 56 b$ & $464 \pm 41 \mathrm{~b}$ & $470 \pm 29 b$ & $603 \pm 78 \mathrm{a}$ & $709 \pm 26 a$ & $705 \pm 48 \mathrm{a}$ \\
\hline & After & $256 \pm 16 b$ & $250 \pm 26 b$ & $249 \pm 25 b$ & $358 \pm 57 \mathrm{a}$ & $410 \pm 82 \mathrm{a}$ & $368 \pm 12 \mathrm{a}$ \\
\hline \multirow[t]{2}{*}{ Extr. Zn (mg/kg) } & Before & $1.0 \pm 0.3 \mathrm{a}$ & $0.7 \pm 0.1 \mathrm{a}$ & $0.7 \pm 0.2 \mathrm{a}$ & $0.9 \pm 0.2 \mathrm{a}$ & $0.8 \pm 0.1 \mathrm{a}$ & $1.0 \pm 0.1 \mathrm{a}$ \\
\hline & After & $4.4 \pm 3.4 \mathrm{ab}$ & $3.9 \pm 3.0 \mathrm{ab}$ & $6.0 \pm 5.7 \mathrm{ab}$ & $8.7 \pm 5.6 \mathrm{a}$ & $1.0 \pm 0.2 \mathrm{~b}$ & $2.4 \pm 1.6 \mathrm{~b}$ \\
\hline
\end{tabular}

Note. Different letters within the rows indicate significant differences $(\mathrm{P} \leq 0.05)$.

\subsection{Mole Ratios of K, Ca and Mg in Soil}

Mole ratios of $\mathrm{K} / \mathrm{Ca}, \mathrm{K} / \mathrm{Mg}$ and $\mathrm{Ca} / \mathrm{Mg}$ are shown in Table 3. The $\mathrm{K} / \mathrm{Ca}$ before treatment application ranged from 0.28 to 0.47 and no significant difference was found between the treatments. After treatment application; T1, T3 and $\mathrm{T} 6$ tended to decrease, whereas the other treatments increased. Increasing of $\mathrm{K}$ concentration (Table 2) and $\mathrm{K} / \mathrm{Ca}$ tatio of $\mathrm{T} 5$ indicate that a farmer applied a significant amount of $\mathrm{K}$. Ca application reduced $\mathrm{K} / \mathrm{Ca}$ ratios of $\mathrm{T} 1, \mathrm{~T} 3$ and $\mathrm{T} 6$, but not that of $\mathrm{T} 2$. The $\mathrm{K} / \mathrm{Mg}$ varied from 0.22 to 0.60 before treatment application. The $\mathrm{K} / \mathrm{Mg}$ of the T1 was significantly higher than that of $\mathrm{T} 5$ before treatment application. Application of $\mathrm{KCl}$ increased the $\mathrm{K} / \mathrm{Mg}$ ratio of $\mathrm{T} 2$ only, whereas the others tended to declined (T1, $\mathrm{T} 4$ and $\mathrm{T} 6$ ). The $\mathrm{Ca} / \mathrm{Mg}$ varied from 0.84 to 1.93 before treatment application. The $\mathrm{Ca} / \mathrm{Mg}$ of $\mathrm{T} 3$ was significantly higher than those of the $\mathrm{T} 5$ and $\mathrm{T} 6$. The results indicated that soils were not homogeneous for these two elements. The $\mathrm{Ca} / \mathrm{Mg}$ tended to increase after $\mathrm{Ca}$ application (T2, T3 and T6) except for that of $\mathrm{T} 1$. The $\mathrm{Ca} / \mathrm{Mg}$ of the $\mathrm{T} 1$ and $\mathrm{T} 4$ declined after treatment application. 
Table 3. Mole ratios of $\mathrm{K} / \mathrm{Ca}, \mathrm{K} / \mathrm{Mg}$ and $\mathrm{Ca} / \mathrm{Mg}$ in soil before and after treatment applications

\begin{tabular}{llllllll}
\hline \multirow{2}{*}{ Mole ration } & \multirow{2}{*}{ Sampling times } & \multicolumn{6}{c}{ Treatments } \\
\cline { 3 - 8 } & & T1 & T2 & T3 & T4 & T5 & T6 \\
\hline \multirow{2}{*}{$\mathrm{K} / \mathrm{Ca}$} & Before & $0.47 \pm 0.20 \mathrm{a}$ & $0.28 \pm 0.13 \mathrm{a}$ & $0.34 \pm 0.18 \mathrm{a}$ & $0.31 \pm 0.20 \mathrm{a}$ & $0.29 \pm 0.19 \mathrm{a}$ & $0.39 \pm 0.12 \mathrm{a}$ \\
& After & $0.37 \pm 0.09 \mathrm{ab}$ & $0.39 \pm 0.20 \mathrm{ab}$ & $0.21 \pm 0.06 \mathrm{~b}$ & $0.32 \pm 0.06 \mathrm{ab}$ & $0.44 \pm 0.28 \mathrm{a}$ & $0.24 \pm 0.06 \mathrm{ab}$ \\
$\mathrm{K} / \mathrm{Mg}$ & Before & $0.60 \pm 0.20 \mathrm{a}$ & $0.41 \pm 0.18 \mathrm{ab}$ & $0.54 \pm 0.10 \mathrm{ab}$ & $0.41 \pm 0.29 \mathrm{ab}$ & $0.22 \pm 0.09 \mathrm{~b}$ & $0.33 \pm 0.11 \mathrm{ab}$ \\
& After & $0.44 \pm 0.14 \mathrm{ab}$ & $0.60 \pm 0.09 \mathrm{a}$ & $0.43 \pm 0.16 \mathrm{ab}$ & $0.34 \pm 0.09 \mathrm{ab}$ & $0.34 \pm 0.12 \mathrm{ab}$ & $0.31 \pm 0.08 \mathrm{~b}$ \\
$\mathrm{Ca} / \mathrm{Mg}$ & Before & $1.33 \pm 0.17 \mathrm{ab}$ & $1.54 \pm 0.49 \mathrm{ab}$ & $1.93 \pm 0.97 \mathrm{a}$ & $1.29 \pm 0.11 \mathrm{ab}$ & $0.85 \pm 0.23 \mathrm{~b}$ & $0.84 \pm 0.20 \mathrm{~b}$ \\
& After & $1.19 \pm 0.17 \mathrm{c}$ & $1.85 \pm 0.89 \mathrm{ab}$ & $2.12 \pm 0.65 \mathrm{a}$ & $1.05 \pm 0.11 \mathrm{c}$ & $0.89 \pm 0.25 \mathrm{c}$ & $1.29 \pm 0.19 \mathrm{bc}$ \\
\hline
\end{tabular}

Note. Different letters within the rows indicate significant differences $(\mathrm{P} \leq 0.05)$.

\subsection{Effects of Treatment Application on Nutrient Uptake}

\subsubsection{Effect of Treatment Application on N Uptake}

Pummelo leaves were collected once before treatment application and at 5,12,16 and 19 months after application. Concentrations of $\mathrm{N}$ in the leaves are shown in Table 4. The $\mathrm{N}$ concentration of $\mathrm{T} 5$ leaves was significantly higher than that of $\mathrm{T} 3$ leaves before the application, whereas theresults for other treatments were not significantly different. The $\mathrm{N}$ concentrations tended to increase after 5 months in all treatments including treatments of no $\mathrm{N}$ application (T2 and T4). Only the $\mathrm{N}$ concentration of leaves from $\mathrm{T} 1$ was above the optimum ranges $(27 \mathrm{~g} / \mathrm{kg}$ to $30 \mathrm{~g} / \mathrm{kg}$ according to Maneepong, 2008 and $25 \mathrm{~g} / \mathrm{kg}$ to $31 \mathrm{~g} / \mathrm{kg}$ according to Zhuang et al., $1991)$ at 5 months. No significant difference was found between treatments at 12 months. At 16 months, the N concentration of $\mathrm{T} 1\left(\left(\mathrm{NH}_{4}\right)_{2} \mathrm{SO}_{4}\right.$ was applied on top of farmer practice) was significantly higher than that of $\mathrm{T} 2$ (no additional $\mathrm{N}$ ). At 19 months, the $\mathrm{N}$ concentrations of all treatments tended to decline. The change may due to pummelo leaves were collected one month prior to harvesting time. Therefore, a large portion of $\mathrm{N}$ was transferred from leaves to fruits. The $\mathrm{N}$ concentration of $\mathrm{T} 5$ (farmer practice) was the lowest and significantly lower than that of the T1. After the treatment application, the $\mathrm{N}$ concentrations of almost all treatments fell in the optimum range and were not clearly distinct between the treatments although the $\mathrm{N}$ fertilizer was not applied.

Table 4. N concentrations $(\mathrm{g} / \mathrm{kg})$ in pummelo leaves before and after treatment application

\begin{tabular}{llllll}
\hline \multirow{2}{*}{ Treatments } & \multicolumn{5}{c}{ Sampling times } \\
\cline { 2 - 6 } & Before & 5 months & 12 months & 16 months & 19 months \\
\hline T1 & $26.4 \pm 0.2 \mathrm{ab}$ & $32.5 \pm 0.1 \mathrm{a}$ & $27.9 \pm 0.1 \mathrm{a}$ & $30.5 \pm 0.1 \mathrm{a}$ & $28.4 \pm 1.9 \mathrm{a}$ \\
T2 & $26.1 \pm 0.2 \mathrm{ab}$ & $29.3 \pm 0.1 \mathrm{~b}$ & $28.0 \pm 0.1 \mathrm{a}$ & $28.3 \pm 0.3 \mathrm{~b}$ & $27.8 \pm 1.7 \mathrm{ab}$ \\
T3 & $25.5 \pm 0.0 \mathrm{~b}$ & $30.2 \pm 0.0 \mathrm{~b}$ & $27.5 \pm 0.1 \mathrm{a}$ & $29.0 \pm 0.1 \mathrm{ab}$ & $28.3 \pm 1.8 \mathrm{ab}$ \\
T4 & $26.6 \pm 0.0 \mathrm{ab}$ & $29.6 \pm 0.2 \mathrm{~b}$ & $28.7 \pm 0.1 \mathrm{a}$ & $29.1 \pm 0.1 \mathrm{ab}$ & $26.5 \pm 1.2 \mathrm{ab}$ \\
T5 & $27.0 \pm 0.1 \mathrm{a}$ & $30.0 \pm 0.2 \mathrm{~b}$ & $28.4 \pm 0.2 \mathrm{a}$ & $29.0 \pm 0.1 \mathrm{ab}$ & $25.7 \pm 1.4 \mathrm{~b}$ \\
T6 & $25.2 \pm 0.1 \mathrm{ab}$ & $30.8 \pm 0.2 \mathrm{ab}$ & $29.3 \pm 0.1 \mathrm{a}$ & $28.8 \pm 0.1 \mathrm{ab}$ & $26.7 \pm 1.9 \mathrm{ab}$ \\
\hline
\end{tabular}

Note. Different letters within the columns indicate significant differences $(\mathrm{P} \leq 0.05)$.

\subsubsection{Effect of Treatment Application on $\mathrm{K}, \mathrm{Ca}$ and Mg Uptake}

$\mathrm{KCl}$ was applied to T1, T2, T4 and T6 plots, although exchangeable $\mathrm{K}$ in soil was higher than the sufficient range (Table 2). Most of the $\mathrm{K}$ concentrations in leaves did not significantly differ between the treatments, except that of T1, which was significantly higher than those of T4, T5 and T6 at 12 months (Table 5). The K of $\mathrm{T} 1$ exhibited the highest values compared with other treatments. Before treatment application, only the $\mathrm{K}$ of the $\mathrm{T} 1 \mathrm{was}$ in the optimum range suggested by Maneepong (2008) $(15 \mathrm{~g} / \mathrm{kg}$ to $20 \mathrm{~g} / \mathrm{kg})$. The highest value of $\mathrm{K} / \mathrm{Mg}$ mole ratio in $\mathrm{T} 1$ soil allowed better $\mathrm{K}$ uptake (Table 3). At 19 months, the $\mathrm{K}$ concentrations declined to lower than the optimum range in all treatments. The $\mathrm{K}$ of $\mathrm{T} 3$ (no $\mathrm{KCl}$ applied by authors) showed the lowest value. Application of $\mathrm{KCl}$ on top of the farmer practice did not show a clear improvement of $\mathrm{K}$ status in the leaves. The exchangeable $\mathrm{Na}$ was significantly higher in $\mathrm{T} 4, \mathrm{~T} 5, \mathrm{~T} 6$ than in the other treatments (Table 2). The inhibition of $\mathrm{K}$ uptake by $\mathrm{Na}$ was clearly showed at 12 months. The $\mathrm{K}$ concentrations of $\mathrm{T} 4$ and $\mathrm{T} 6$ ( $\mathrm{KCl}$ was applied) were lower than that of the $\mathrm{T} 3$ ( $\mathrm{KCl}$ was not applied). Pummelo cannot uptake $\mathrm{K}$ to a sufficient level despite the excessive $\mathrm{K}$ in the soil. High concentration of $\mathrm{Mg}$ and low $\mathrm{K} / \mathrm{Mg}$ ratio in soil negatively affected $\mathrm{K}$ uptake by 
pummelo. An antagonism between $\mathrm{K}$ and Mg was previously described (Jones, 1999; Kasiath \& Senthikumar, 2015; Kirkby \& Mengel, 1976).

Table 5. K concentrations $(\mathrm{g} / \mathrm{kg})$ in pummelo leaves before and after treatment application

\begin{tabular}{llllll}
\hline \multirow{2}{*}{ Treatments } & \multicolumn{5}{c}{ Sampling times } \\
\cline { 2 - 6 } & Before & 5 months & 12 months & 16 months & 19 months \\
\hline T1 & $15.1 \pm 2.9 \mathrm{a}$ & $16.4 \pm 1.3 \mathrm{a}$ & $17.1 \pm 1.6 \mathrm{a}$ & $16.5 \pm 4.8 \mathrm{a}$ & $14.1 \pm 0.9 \mathrm{a}$ \\
T2 & $12.6 \pm 1.3 \mathrm{a}$ & $14.9 \pm 1.1 \mathrm{a}$ & $15.4 \pm 3.6 \mathrm{ab}$ & $16.2 \pm 4.1 \mathrm{a}$ & $13.8 \pm 2.1 \mathrm{a}$ \\
T3 & $14.5 \pm 1.7 \mathrm{a}$ & $14.1 \pm 0.9 \mathrm{a}$ & $15.6 \pm 1.7 \mathrm{ab}$ & $15.9 \pm 1.2 \mathrm{a}$ & $11.9 \pm 1.4 \mathrm{a}$ \\
T4 & $14.0 \pm 2.7 \mathrm{a}$ & $14.8 \pm 2.4 \mathrm{a}$ & $13.0 \pm 3.2 \mathrm{~b}$ & $14.4 \pm 1.2 \mathrm{a}$ & $12.8 \pm 1.0 \mathrm{a}$ \\
T5 & $13.6 \pm 1.2 \mathrm{a}$ & $14.3 \pm 1.9 \mathrm{a}$ & $14.0 \pm 1.1 \mathrm{~b}$ & $16.3 \pm 0.8 \mathrm{a}$ & $12.0 \pm 2.2 \mathrm{a}$ \\
T6 & $13.6 \pm 0.9 \mathrm{a}$ & $14.2 \pm 3.3 \mathrm{a}$ & $14.0 \pm 1.0 \mathrm{~b}$ & $15.0 \pm 0.7 \mathrm{a}$ & $12.0 \pm 0.6 \mathrm{a}$ \\
\hline
\end{tabular}

Note. Different letters within the columns indicate significant differences $(\mathrm{P} \leq 0.05)$.

$\mathrm{Ca}$ was applied to $\mathrm{T} 1, \mathrm{~T} 2$ and $\mathrm{T} 3$ in the form of $\mathrm{CaSO}_{4} \cdot 2 \mathrm{H}_{2} \mathrm{O}$ and to $\mathrm{T} 6$ in the form of $5 \mathrm{Ca}\left(\mathrm{NO}_{3}\right)_{2} \cdot \mathrm{NH}_{4} \mathrm{NO}_{3} \cdot 10 \mathrm{H}_{2} \mathrm{O}$, although the exchangeable $\mathrm{Ca}$ in soil was higher than the opptimum range $(1,000$ $\mathrm{mg} / \mathrm{kg}$ to 2,000 mg/kg; Maneepong, 2008). An optimum range of $\mathrm{Ca}$ in pummelo leaves gieven by Maneepong (2008) was $30 \mathrm{mg} / \mathrm{kg}$ to $40 \mathrm{mg} / \mathrm{kg}$, whereas Zhuang et al. (1991) suggested a lower range of $20 \mathrm{mg} / \mathrm{kg}$ to 38 $\mathrm{mg} / \mathrm{kg}$. Ca concentrations in leaves collected from T1, T2 and T3 tended to be higher than those from T4, T5 and T6 throughout the observation period (Table 6). The trend corresponded to exchangeable Na in the soil (Table 2). High $\mathrm{Na}$ in the soil inhibited Ca uptake by pummelo. B. K. Garg and O. P. Garg (1980) reported that the uptake of all nutrients except $\mathrm{Na}$ decreased significantly due to salt application, while the uptake of N, P and $\mathrm{K}$ declined at higher salt concentration and only towards later stage of plant growth; the uptake of $\mathrm{Ca}$ and $\mathrm{Mg}$ decreased right from early growth. According to Majeed et al. (2010), increase in $\mathrm{NaCl}$ concentration in the culture medium caused a progressive decreased of $\mathrm{K}$ uptake in the roots and stems of both the clones. Na concentrations increased with increasing $\mathrm{NaCl}$ levels, whereas $\mathrm{K}$ concentration and $\mathrm{K} / \mathrm{Na}$ ratio decreased with increasing $\mathrm{NaCl}$ level (Yousufinia, Ghasemian, Safalian, \& Asadi, 2013).

Ca concentration in the leaves of $\mathrm{T} 3$ was highest before the treatment application and significantly higher than those of T4, T5 and T6 and at 5 months (Table 6). The leaf concentration corresponded to exchangeable Ca in soil and mole ratio of $\mathrm{Ca} / \mathrm{Mg}$ (Tables 2 and 3). High $\mathrm{Ca}$ in soil together with low $\mathrm{Mg}$ tended to promote Ca uptake. Schimanski (1981) also found that Mg strongly modified the uptake of $\mathrm{Ca}$ in case of barley seedling grown using hydroponics.

Table 6. Ca concentrations $(\mathrm{g} / \mathrm{kg})$ in pummelo leaves before and after treatment application

\begin{tabular}{llllll}
\hline \multirow{2}{*}{ Treatments } & \multicolumn{5}{c}{ Sampling times } \\
\cline { 2 - 5 } & Before & 5 months & 12 months & 16 months & 19 months \\
\hline T1 & $36 \pm 13 \mathrm{ab}$ & $31 \pm 3 \mathrm{a}$ & $28 \pm 5 \mathrm{ab}$ & $33 \pm 6 \mathrm{a}$ & $39 \pm 2 \mathrm{a}$ \\
T2 & $37 \pm 7 \mathrm{ab}$ & $32 \pm 6 \mathrm{a}$ & $34 \pm 5 \mathrm{a}$ & $27 \pm 3 \mathrm{~b}$ & $31 \pm 5 \mathrm{~b}$ \\
T3 & $41 \pm 5 \mathrm{a}$ & $32 \pm 4 \mathrm{a}$ & $32 \pm 6 \mathrm{ab}$ & $27 \pm 4 \mathrm{~b}$ & $34 \pm 6 \mathrm{ab}$ \\
T4 & $27 \pm 4 \mathrm{bc}$ & $25 \pm 2 \mathrm{~b}$ & $27 \pm 6 \mathrm{~b}$ & $26 \pm 2 \mathrm{~b}$ & $28 \pm 3 \mathrm{~b}$ \\
T5 & $25 \pm 5 \mathrm{c}$ & $29 \pm 2 \mathrm{ab}$ & $30 \pm 2 \mathrm{ab}$ & $25 \pm 1 \mathrm{~b}$ & $29 \pm 4 \mathrm{~b}$ \\
T6 & $23 \pm 3 \mathrm{c}$ & $28 \pm 0 \mathrm{ab}$ & $26 \pm 5 \mathrm{~b}$ & $26 \pm 1 \mathrm{~b}$ & $32 \pm 1 \mathrm{ab}$ \\
\hline
\end{tabular}

Note. Different letters within the columns indicate significant differences $(\mathrm{P} \leq 0.05)$.

$\mathrm{Mg}$ concentrations in leaves had no significant differences between treatments both before and at 12 months of application (Table 7). It was significantly lower in T3 than in the others except T4 at 5 months. The Mg tended to increase at 19 months compared with the previous sampling times, whereas the $\mathrm{K}$ tended to decrease (Table 5 and 7). The $\mathrm{Mg}$ at nearly all sampling times were higher than their optimum ranges $(3 \mathrm{~g} / \mathrm{kg}$ to $5 \mathrm{~g} / \mathrm{kg}$ according to Maneepong (2008) and $3.2 \mathrm{~g} / \mathrm{kg}$ to $4.7 \mathrm{~g} / \mathrm{kg}$ according to Zhuang et al. (1991)), indicating that the Mg uptake by pummelo was greater than its requirement. Kirkby and Mengel (1976) and Zamaniyan et al. (2012) suggested that high $\mathrm{Mg}$ concentration either in soil or plant is often a cause of poor $\mathrm{K}$ status in plant. We also found that 
$\mathrm{Mg}$ in leaves tended to negatively correlate with K (Figure 1). This finding supports the antagonistic effect of Mg on K uptake.

Table 7. Mg concentrations $(\mathrm{g} / \mathrm{kg})$ in pummelo leaves before and after treatment application

\begin{tabular}{llllll}
\hline \multirow{2}{*}{ Treatments } & \multicolumn{5}{c}{ Sampling times } \\
\cline { 2 - 6 } & Before & 5 months & 12 months & 16 months & 19 months \\
\hline T1 & $6.2 \pm 0.8 \mathrm{a}$ & $6.4 \pm 0.5 \mathrm{a}$ & $5.7 \pm 0.3 \mathrm{a}$ & $5.9 \pm 0.5 \mathrm{a}$ & $6.5 \pm 0.7 \mathrm{ab}$ \\
T2 & $6.0 \pm 0.6 \mathrm{a}$ & $6.4 \pm 0.4 \mathrm{a}$ & $6.1 \pm 1.1 \mathrm{a}$ & $4.9 \pm 0.4 \mathrm{~b}$ & $5.9 \pm 0.4 \mathrm{~b}$ \\
T3 & $5.9 \pm 0.9 \mathrm{a}$ & $5.7 \pm 0.3 \mathrm{~b}$ & $5.4 \pm 0.9 \mathrm{a}$ & $4.8 \pm 0.2 \mathrm{~b}$ & $5.7 \pm 0.3 \mathrm{~b}$ \\
T4 & $6.0 \pm 0.9 \mathrm{a}$ & $6.1 \pm 0.4 \mathrm{ab}$ & $5.8 \pm 0.5 \mathrm{a}$ & $5.5 \pm 0.6 \mathrm{a}$ & $6.4 \pm 0.3 \mathrm{~b}$ \\
T5 & $6.1 \pm 0.9 \mathrm{a}$ & $6.7 \pm 0.5 \mathrm{a}$ & $6.1 \pm 0.3 \mathrm{a}$ & $5.5 \pm 0.3 \mathrm{a}$ & $7.2 \pm 0.4 \mathrm{a}$ \\
T6 & $5.7 \pm 0.9 \mathrm{a}$ & $6.5 \pm 0.4 \mathrm{a}$ & $5.4 \pm 0.4 \mathrm{a}$ & $5.1 \pm 0.5 \mathrm{ab}$ & $6.5 \pm 0.8 \mathrm{ab}$ \\
\hline
\end{tabular}

Note. Different letters within the columns indicate significant differences $(\mathrm{P} \leq 0.05)$.

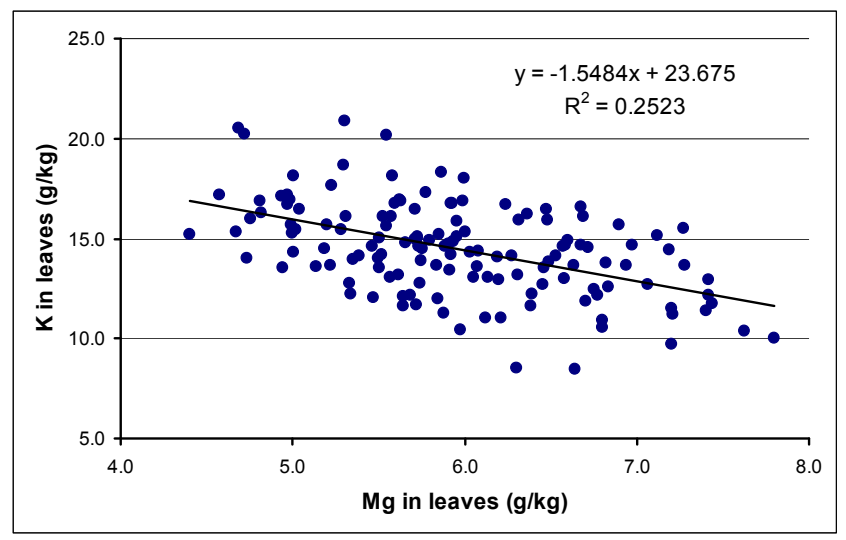

Figure 1. Correlation between concentrations of $\mathrm{Mg}$ and $\mathrm{K}$ in pummelo leaves

\subsubsection{Effect of Treatment Application on Mole Ratios of $\mathrm{K}, \mathrm{Ca}$ and $\mathrm{Mg}$ in Leaves}

Mole ratios of $\mathrm{K} / \mathrm{Ca}, \mathrm{K} / \mathrm{Mg}$ and $\mathrm{Ca} / \mathrm{Mg}$ in pummelo leaves both before and 5, 12, 16 and 19 months after treatment application are shown in Table 8 . The $\mathrm{K} / \mathrm{Ca}$ of $\mathrm{T} 5$ before application was significantly higher than those of T2 and T3. After 5 months of application, the K/Ca of T4 was the highest and significantly higher than hose of $\mathrm{T} 2$ and $\mathrm{T} 3$. No significant difference was found between treatments after 5 months. $\mathrm{KCl}$ was not applied to $\mathrm{T} 3$, but the $\mathrm{K} / \mathrm{Ca}$ increased possibly due to excess concentration of $\mathrm{K}$ in the soil.

The K/Mg ratios were not significantly different between treatments until 19 months. The $\mathrm{K} / \mathrm{Mg}$ of $\mathrm{T} 2$ was the highest and significantly higher than those of the $\mathrm{T} 5$ and $\mathrm{T} 6$, which had high concentrations of $\mathrm{Mg}$ and $\mathrm{Na}$ in the soils (Table 2). The result indicated that both $\mathrm{Mg}$ and $\mathrm{Na}$ inhibit $\mathrm{K}$ uptake of pummelo.

$\mathrm{The} \mathrm{Ca} / \mathrm{Mg}$ ratios varied in a widely between treatments both before and after application. The $\mathrm{Ca} / \mathrm{Mg}$ of $\mathrm{T} 1, \mathrm{~T} 2$ and $\mathrm{T} 3$ tended to be higher than those of T4, T5 and T6. This may due to $\mathrm{CaSO}_{4} \cdot 2 \mathrm{H}_{2} \mathrm{O}$ application together with low $\mathrm{Mg}$ and $\mathrm{Na}$ in the soils. The $\mathrm{Ca} / \mathrm{Mg}$ of $\mathrm{T} 6$ tended to increase after treatment application, because this treatment received $5 \mathrm{Ca}\left(\mathrm{NO}_{3}\right)_{2} \cdot \mathrm{NH}_{4} \mathrm{NO}_{3} \cdot 10 \mathrm{H}_{2} \mathrm{O}$. Ca uptake tended to be faster when its concentration increased at low concentrations of $\mathrm{Mg}$ and $\mathrm{Na}$ in the soil. 
Table 8. Mole ratios of $\mathrm{K} / \mathrm{Ca}, \mathrm{K} / \mathrm{Mg}$ and $\mathrm{Ca} / \mathrm{Mg}$ in pummelo leaves before and after treatment applications

\begin{tabular}{llllllll}
\hline \multirow{2}{*}{ Mole ratios } & Sampling times & \multicolumn{5}{c}{ Treatments } \\
\cline { 3 - 7 } & & T1 & T2 & T3 & T4 & T5 \\
\hline $\mathrm{K} / \mathrm{Ca}$ & Before & $0.49 \pm 0.20 \mathrm{ab}$ & $0.36 \pm 0.09 \mathrm{~b}$ & $0.37 \pm 0.09 \mathrm{~b}$ & $0.55 \pm 0.17 \mathrm{ab}$ & $0.58 \pm 0.15 \mathrm{a}$ & $0.61 \pm 0.11 \mathrm{a}$ \\
& 5 months & $0.55 \pm 0.04 \mathrm{ab}$ & $0.49 \pm 0.08 \mathrm{~b}$ & $0.47 \pm 0.08 \mathrm{~b}$ & $0.62 \pm 0.12 \mathrm{a}$ & $0.52 \pm 0.09 \mathrm{ab}$ & $0.52 \pm 0.12 \mathrm{ab}$ \\
& 12 months & $0.64 \pm 0.16 \mathrm{a}$ & $0.49 \pm 0.20 \mathrm{a}$ & $0.50 \pm 0.06 \mathrm{a}$ & $0.53 \pm 0.19 \mathrm{a}$ & $0.48 \pm 0.05 \mathrm{a}$ & $0.56 \pm 0.09 \mathrm{a}$ \\
& 16 months & $0.55 \pm 0.24 \mathrm{a}$ & $0.61 \pm 0.15 \mathrm{a}$ & $0.62 \pm 0.09 \mathrm{a}$ & $0.56 \pm 0.08 \mathrm{a}$ & $0.68 \pm 0.06 \mathrm{a}$ & $0.60 \pm 0.05 \mathrm{a}$ \\
$\mathrm{K} / \mathrm{Mg}$ & 19 months & $0.38 \pm 0.03 \mathrm{a}$ & $0.46 \pm 0.11 \mathrm{a}$ & $0.36 \pm 0.06 \mathrm{a}$ & $0.48 \pm 0.09 \mathrm{a}$ & $0.43 \pm 0.13 \mathrm{a}$ & $0.38 \pm 0.02 \mathrm{a}$ \\
& Before & $1.57 \pm 0.45 \mathrm{a}$ & $1.31 \pm 0.21 \mathrm{a}$ & $1.57 \pm 0.39 \mathrm{a}$ & $1.49 \pm 0.48 \mathrm{a}$ & $1.42 \pm 0.33 \mathrm{a}$ & $1.50 \pm 0.23 \mathrm{a}$ \\
& 5 months & $1.61 \pm 0.20 \mathrm{a}$ & $1.44 \pm 0.13 \mathrm{a}$ & $1.54 \pm 0.13 \mathrm{a}$ & $1.52 \pm 0.31 \mathrm{a}$ & $1.34 \pm 0.25 \mathrm{a}$ & $1.37 \pm 0.37 \mathrm{a}$ \\
\cline { 3 - 7 } $\mathrm{Ca} / \mathrm{Mg}$ & 12 months & $1.87 \pm 0.25 \mathrm{a}$ & $1.65 \pm 0.69 \mathrm{a}$ & $1.86 \pm 0.43 \mathrm{a}$ & $1.43 \pm 0.44 \mathrm{a}$ & $1.42 \pm 0.18 \mathrm{a}$ & $1.60 \pm 0.09 \mathrm{a}$ \\
& 16 months & $1.79 \pm 0.66 \mathrm{a}$ & $2.05 \pm 0.50 \mathrm{a}$ & $2.08 \pm 0.21 \mathrm{a}$ & $1.64 \pm 0.25 \mathrm{a}$ & $1.83 \pm 0.16 \mathrm{a}$ & $1.86 \pm 0.24 \mathrm{a}$ \\
& 19 months & $1.35 \pm 0.09 \mathrm{ab}$ & $1.43 \pm 0.16 \mathrm{a}$ & $1.31 \pm 0.21 \mathrm{ab}$ & $1.25 \pm 0.13 \mathrm{abc}$ & $1.04 \pm 0.20 \mathrm{c}$ & $1.16 \pm 0.19 \mathrm{bc}$ \\
& Before & $3.41 \pm 0.20 \mathrm{~b}$ & $3.71 \pm 0.43 \mathrm{ab}$ & $4.19 \pm 0.44 \mathrm{a}$ & $2.73 \pm 0.40 \mathrm{c}$ & $2.45 \pm 0.20 \mathrm{c}$ & $2.46 \pm 0.33 \mathrm{c}$ \\
& 5 months & $2.92 \pm 0.20 \mathrm{bc}$ & $3.00 \pm 0.04 \mathrm{~b}$ & $3.67 \pm 0.47 \mathrm{a}$ & $2.46 \pm 0.19 \mathrm{~d}$ & $2.61 \pm 0.13 \mathrm{~cd}$ & $2.60 \pm 0.17 \mathrm{~cd}$ \\
& 12 months & $3.01 \pm 0.36 \mathrm{a}$ & $3.39 \pm 0.41 \mathrm{a}$ & $3.76 \pm 1.04 \mathrm{a}$ & $2.82 \pm 0.45 \mathrm{a}$ & $2.97 \pm 0.18 \mathrm{a}$ & $2.89 \pm 0.39 \mathrm{a}$ \\
& 16 months & $3.37 \pm 0.34 \mathrm{ab}$ & $3.36 \pm 0.16 \mathrm{ab}$ & $3.45 \pm 0.61 \mathrm{a}$ & $2.93 \pm 0.19 \mathrm{bc}$ & $2.71 \pm 0.18 \mathrm{c}$ & $3.08 \pm 0.43 \mathrm{abc}$ \\
& 19 months & $3.62 \pm 0.36 \mathrm{a}$ & $3.22 \pm 0.58 \mathrm{ab}$ & $3.70 \pm 0.72 \mathrm{a}$ & $2.65 \pm 0.22 \mathrm{bc}$ & $2.45 \pm 0.35 \mathrm{c}$ & $3.04 \pm 0.44 \mathrm{abc}$ \\
\hline
\end{tabular}

Note. Different letters within the rows indicate significant differences $(\mathrm{P} \leq 0.05)$.

\subsubsection{Effects of Treatment Application on Zn Uptake}

The $\mathrm{Zn}$ concentrations in leaves before application were lower than their optimum ranges for pummelo ( $>15$ $\mathrm{mg} / \mathrm{kg}$ according to Maneepong (2008) and $24 \mathrm{mg} / \mathrm{kg}$ to $44 \mathrm{mg} / \mathrm{kg}$ according to Zhuang et al. (1991)) (Table 9). Application of $\mathrm{ZnSO}_{4} \cdot 7 \mathrm{H}_{2} \mathrm{O}$ increased $\mathrm{Zn}$ concentrations in soils (Table 2) and in the leaves to the optimum range suggested by Maneepong (2008). High $\mathrm{pH}$ and available $\mathrm{P}$ in soil inhibited the uptake of $\mathrm{Zn}$ by pummelo. According to Fageria (2000), increasing the $\mathrm{pH}$ in soil from 4.6 to 6.8 decreased the uptake of $\mathrm{Zn}$ by rice. $\mathrm{Zn}$ absorption capacity is reduced by high phosphorus utilization and $\mathrm{Zn}$ in plant and soil has an antagonism with phosphorus (Sayed, 2011). Moreover, high concentration of P in soil results in the formation of zinc phosphate, which is difficult to dissolve (Pendias, 1992).

Table 9. $\mathrm{Zn}$ concentrations $(\mathrm{mg} / \mathrm{kg})$ in pummelo leaves before and after treatment application

\begin{tabular}{llllll}
\hline \multirow{2}{*}{ Treatments } & \multicolumn{5}{c}{ Sampling times } \\
\cline { 2 - 6 } & Before & 5 months & 12 months & 16 months & 19 months \\
\hline T1 & $13.4 \pm 1.6 \mathrm{a}$ & $17.7 \pm 2.3 \mathrm{ab}$ & $18.6 \pm 0.5 \mathrm{a}$ & $18.7 \pm 3.4 \mathrm{a}$ & $18.9 \pm 1.5 \mathrm{ab}$ \\
$\mathrm{T} 2$ & $11.7 \pm 1.4 \mathrm{~b}$ & $18.6 \pm 4.2 \mathrm{ab}$ & $16.8 \pm 3.1 \mathrm{a}$ & $14.1 \pm 3.3 \mathrm{~b}$ & $15.2 \pm 0.8 \mathrm{c}$ \\
T3 & $12.6 \pm 0.6 \mathrm{ab}$ & $19.7 \pm 3.0 \mathrm{a}$ & $16.6 \pm 1.7 \mathrm{a}$ & $15.3 \pm 2.3 \mathrm{~b}$ & $15.4 \pm 3.1 \mathrm{c}$ \\
T4 & $12.4 \pm 1.1 \mathrm{ab}$ & $15.9 \pm 2.8 \mathrm{~b}$ & $17.5 \pm 2.8 \mathrm{a}$ & $18.6 \pm 1.5 \mathrm{a}$ & $19.9 \pm 1.2 \mathrm{a}$ \\
T5 & $12.8 \pm 0.9 \mathrm{ab}$ & $17.2 \pm 1.2 \mathrm{ab}$ & $16.8 \pm 2.1 \mathrm{a}$ & $15.2 \pm 1.2 \mathrm{~b}$ & $17.5 \pm 1.5 \mathrm{abc}$ \\
T6 & $12.0 \pm 0.3 \mathrm{ab}$ & $18.1 \pm 3.5 \mathrm{ab}$ & $16.4 \pm 0.7 \mathrm{a}$ & $15.0 \pm 0.7 \mathrm{~b}$ & $16.8 \pm 1.2 \mathrm{bc}$ \\
\hline
\end{tabular}

Note. Different letters within the columns indicate significant differences $(\mathrm{P} \leq 0.05)$.

\subsection{Effects of Treatment Application on Fruit Quality}

Pummelo fruits were collected twice on the first and second years of the experiment. A medium size of fully ripened pummelo fruit was collected from each replication. Peel thickness, juice ratio, $\mathrm{pH}$, TSS, TA and TSS/TA were measured and analyzed. The results are shown in Table 10 and 11. Mean values of the peel thickness ranged from $0.8 \mathrm{~cm}$ to $1.2 \mathrm{~cm}$, thinner than generally accepted at $1.5 \mathrm{~cm}$ (Maneepong, 2013). The peels of T2 and $\mathrm{T} 5$ were significantly thinner than those of $\mathrm{T} 4$ and $\mathrm{T} 6$ on the first year. The peel of $\mathrm{T} 1$ was significantly thinner than those of T2, T3 and T4 on the second year. Edible portions were significantly low in T4 and T6, whereas that of the T2 showed the highest mean value on the first year. The edible portions increased above $70 \%$ for all treatments on the second year. The edible portion of $\mathrm{T} 1$ was highest, and significantly differed from those 
of the other treatments. Juice ratio of $\mathrm{T} 2$ was the highest and significantly differed from that of the $\mathrm{T} 4$ on the first year. However, juice ratio of $\mathrm{T} 1$ was the highest on the second year. N, K, Ca and $\mathrm{Zn}$ fertilizers were applied on pummelo trees of T1, and the $\mathrm{K}$ in leaves tended to be higher than the others (Table 5). Effects of the treatments on peel thickness, edible portion, and juice ratio distinctly showed on the second year. The juice ratio tended to positively correlate with the edible portion, and negatively correlate with the peel thickness (Figures 2 and 3).

TSS of T3 was the lowest and significant difference from those of T4 and T5 on the first year. On the second year, TSS of the T3 was still lowest and significant difference from those of T4 and T5. KCl was not applied on the T3, but $\mathrm{K}$ in leaves did not significantly differ from the other treatments (Table 5). After application, K/Ca ratio in soil tended to be the lowest, and $\mathrm{Ca} / \mathrm{Mg}$ tended to be the highest. These ion ratios may affecte the TSS.

No significant difference of TA was found between treatments, both on the first and second years (Tables 10 and 11). TSS/TA is generally used as a test index for indicating balance of sweet and sour. High TSS/TA indicates better taste of fruit juice. Fruits collected from T5 gave the highest mean value of TSS/TA on the first year, and significantly different from those of T1, T2, T3 and T6. The results were caused by relatively high TSS and low TA. Fruits collected from T6 gave the highest mean TSS/TA, and those from T1 gave the lowest on the second year. $\mathrm{pH}$ of the fruit juice had small difference between treatments, with no significant difference on the second year. The $\mathrm{pH}$ tended to positively correlate with TSS/TA and negatively correlate with TA, but the $\mathrm{pH}$ was not sensitive as the two parameters. Nazanza (2006) reported that high $\mathrm{Ca} / \mathrm{Mg}$ ratios in solution decreased the $\mathrm{pH}$ of tomato fruit juice, which was also reduced by increasing of $\mathrm{K}$ concentration in the nutrient solution.

Table 10. Properties of pummelo fruits collected on the first year of the experiment

\begin{tabular}{lllllll}
\hline \multirow{2}{*}{ Fruit quality } & \multicolumn{5}{c}{ Treatments } \\
\cline { 2 - 6 } & $\mathrm{T} 1$ & $\mathrm{~T} 2$ & $\mathrm{~T} 3$ & $\mathrm{~T} 4$ & $\mathrm{~T} 5$ & $\mathrm{~T} 6$ \\
\hline Peel thickness (cm) & $1.1 \pm 0.1 \mathrm{ab}$ & $0.9 \pm 0.1 \mathrm{~b}$ & $1.0 \pm 0.1 \mathrm{ab}$ & $1.2 \pm 0.2 \mathrm{a}$ & $0.9 \pm 0.1 \mathrm{~b}$ & $1.2 \pm 0.1 \mathrm{a}$ \\
Edible portion (\%) & $70.7 \pm 1.5 \mathrm{ab}$ & $73.8 \pm 1.3 \mathrm{a}$ & $71.7 \pm 1.7 \mathrm{ab}$ & $69.0 \pm 3.1 \mathrm{~b}$ & $73.5 \pm 2.4 \mathrm{a}$ & $68.0 \pm 2.2 \mathrm{~b}$ \\
Juice ratio (m1/kg) & $419 \pm 16 \mathrm{ab}$ & $436 \pm 13 \mathrm{a}$ & $428 \pm 15 \mathrm{ab}$ & $400 \pm 36 \mathrm{~b}$ & $430 \pm 27 \mathrm{ab}$ & $405 \pm 30 \mathrm{ab}$ \\
TSS & $14.1 \pm 0.2 \mathrm{ab}$ & $14.5 \pm 1.1 \mathrm{ab}$ & $13.3 \pm 1.7 \mathrm{~b}$ & $15.5 \pm 0.6 \mathrm{a}$ & $15.3 \pm 0.7 \mathrm{a}$ & $14.2 \pm 1.5 \mathrm{ab}$ \\
TA (\%w/v) & $0.46 \pm 0.03 \mathrm{a}$ & $0.44 \pm 0.08 \mathrm{a}$ & $0.43 \pm 0.05 \mathrm{a}$ & $0.45 \pm 0.07 \mathrm{a}$ & $0.38 \pm 0.03 \mathrm{a}$ & $0.41 \pm 0.02 \mathrm{a}$ \\
TSS/TA & $31 \pm 2 \mathrm{~b}$ & $34 \pm 4 \mathrm{~b}$ & $31 \pm 5 \mathrm{~b}$ & $35 \pm 4 \mathrm{ab}$ & $41 \pm 4 \mathrm{a}$ & $35 \pm 5 \mathrm{~b}$ \\
pH & $4.2 \pm 0.0 \mathrm{c}$ & $4.3 \pm 0.1 \mathrm{bc}$ & $4.3 \pm 0.1 \mathrm{bc}$ & $4.3 \pm 0.1 \mathrm{bc}$ & $4.5 \pm 0.1 \mathrm{a}$ & $4.4 \pm 0.1 \mathrm{ab}$ \\
\hline
\end{tabular}

Note. Different letters within the rows indicate significant differences $(\mathrm{P} \leq 0.05)$.

Table 11. Properties of pummelo fruits collected on the second year of the experiment

\begin{tabular}{lllllll}
\hline \multirow{2}{*}{ Fruit quality } & \multicolumn{5}{c}{ Treatments } \\
\cline { 2 - 6 } & $\mathrm{T} 1$ & $\mathrm{~T} 2$ & $\mathrm{~T} 3$ & $\mathrm{~T} 4$ & $\mathrm{~T} 5$ & $\mathrm{~T} 6$ \\
\hline Peel thickness (cm) & $0.8 \pm 0.1 \mathrm{~b}$ & $1.2 \pm 0.4 \mathrm{a}$ & $1.1 \pm 0.1 \mathrm{a}$ & $1.1 \pm 0.1 \mathrm{a}$ & $1.0 \pm 0.1 \mathrm{ab}$ & $1.0 \pm 0.1 \mathrm{ab}$ \\
Edible portion (\%) & $75.9 \pm 2.3 \mathrm{a}$ & $72.2 \pm 2.5 \mathrm{~b}$ & $72.4 \pm 1.2 \mathrm{~b}$ & $71.9 \pm 0.8 \mathrm{~b}$ & $71.8 \pm 2.0 \mathrm{~b}$ & $72.5 \pm 1.4 \mathrm{~b}$ \\
Juice ratio (m1/kg) & $512 \pm 14 \mathrm{a}$ & $485 \pm 26 \mathrm{~b}$ & $477 \pm 25 \mathrm{~b}$ & $475 \pm 7 \mathrm{~b}$ & $484 \pm 21 \mathrm{~b}$ & $477 \pm 15 \mathrm{~b}$ \\
TSS & $13.0 \pm 0.2 \mathrm{~cd}$ & $13.0 \pm 0.5 \mathrm{~cd}$ & $12.6 \pm 0.4 \mathrm{~d}$ & $13.5 \pm 0.5 \mathrm{bc}$ & $14.0 \pm 0.3 \mathrm{ab}$ & $14.3 \pm 0.5 \mathrm{a}$ \\
TA (\%w/v) & $0.61 \pm 0.03 \mathrm{a}$ & $0.58 \pm 0.08 \mathrm{a}$ & $0.59 \pm 0.05 \mathrm{a}$ & $0.58 \pm 0.02 \mathrm{a}$ & $0.61 \pm 0.06 \mathrm{a}$ & $0.57 \pm 0.08 \mathrm{a}$ \\
TSS/TA & $22 \pm 2 \mathrm{~b}$ & $23 \pm 3 \mathrm{ab}$ & $22 \pm 2 \mathrm{~b}$ & $23 \pm 2 \mathrm{ab}$ & $23 \pm 2 \mathrm{ab}$ & $26 \pm 4 \mathrm{a}$ \\
pH & $3.8 \pm 0.1 \mathrm{a}$ & $3.9 \pm 0.1 \mathrm{a}$ & $3.8 \pm 0.1 \mathrm{a}$ & $3.8 \pm 0.1 \mathrm{a}$ & $3.8 \pm 0.0 \mathrm{a}$ & $3.8 \pm 0.1 \mathrm{a}$ \\
\hline
\end{tabular}

Note. Different letters within the rows indicate significant differences $(\mathrm{P} \leq 0.05)$. 


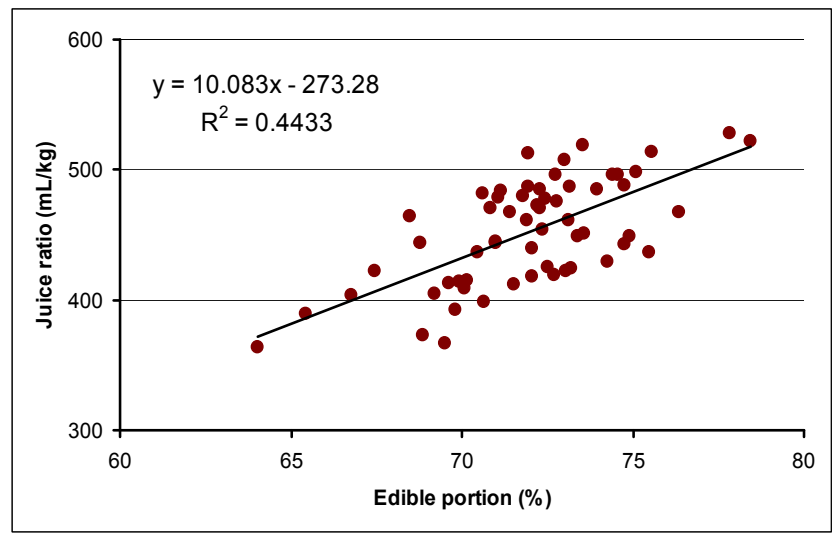

Figure 2. Correlation between edible portion and juice ratio of pummelo collected in first and second years of the experiment

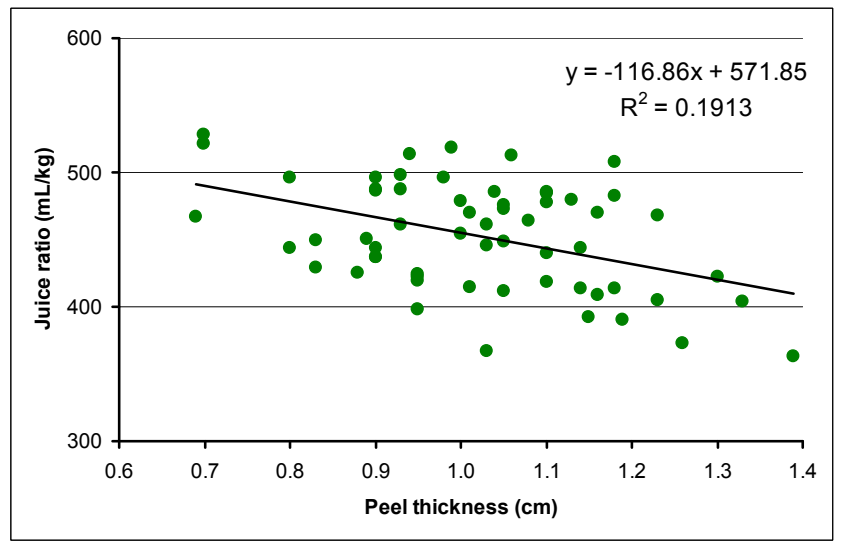

Figure 3. Correlation between peel thickness and juice ratio of pummelo collected in first year and second year of experiment

\section{Conclusions}

The soil $\mathrm{pH}$ was neutral and salinity was slightly saline. Exchangeable $\mathrm{K}, \mathrm{Ca}$ and $\mathrm{Mg}$ were higher than their optimum ranges. The extractable $\mathrm{Zn}$ in the soil and $\mathrm{Zn}$ in the leaves were lower than their optimum ranges. However, the problem can be solved by a single application $(250 \mathrm{~g} /$ tree $)$ of $\mathrm{ZnSO}_{4} \cdot 7 \mathrm{H}_{2} \mathrm{O}$. Pummelo can not uptake $\mathrm{K}$ to a sufficient level even though it is abundant in soil. High exchangeable $\mathrm{Na}$ and low $\mathrm{K} / \mathrm{Mg}$ mole ratio in soil inhibited $\mathrm{K}$ uptake. Concentration of $\mathrm{Ca}$ in leaves correspond with $\mathrm{Ca}$ and $\mathrm{Ca} / \mathrm{Mg}$ mole ratio in the soil. Concentrations of $\mathrm{Mg}$ and $\mathrm{K}$ in leaves negatively correlated with each other. High $\mathrm{Mg}$ and $\mathrm{Na}$ in the soil inhibited the uptake of $\mathrm{K}$ and $\mathrm{Ca}$, thereby causing a luxury consumption of $\mathrm{Mg}$. The fruit qualities were greater in the treatment with mole ratios of $\mathrm{K} / \mathrm{Ca}, \mathrm{K} / \mathrm{Mg}$ and $\mathrm{Ca} / \mathrm{Mg}$ were 0.24 to $0.44,0.31$ to 0.44 and 0.89 to 1.29 , respectively. Juice ratio of the pummelo positively correlated with edible portion and negatively correlated with peel thickness.

\section{Acknowledgements}

This study was partially supported by the Thailand Research Fund. The authors are grateful to the Center of Scientific Equipment, Walailak University, Thailand for the support of equipment and facilities.

\section{References}

Bar-Tal, A., \& Pressaman, E. (1996). Root restriction and potassium and calcium solutions concentration affect dry-matter production, cation uptake and blossom-end rot in greenhouse tomato. Journal of the American Society for Horticultural Science, 121, 649-655.

Bergmann, W. (1992). Nutritional disorders of plants. Germany: Development, Visual and Analytical Diagnosis. 
Boland, F. E. (1995). Acidity (titraable) of fruit products. In P. Cunniff (Ed.), Official Methods of Analysis of the Association Official Analytical Chemist International (6th ed., p. 2). Virginia, America: AOAC international.

Fageria, N. K. (2000). Upland rice response to soil acidity in cerrado soil. Pesq. Agropec. Bas, 35, $2303-2307$. https://doi.org/10.1590/S0100-204X2000001100024

Garg, B. K., \& Garg, O. P. (1980). Salinity and plant nutrition-Effect of sodium carbonate and sodium bicarbonate on growth and absorption of essential macro-nutrients and sodium in pea (Pisum sativum L.). Proceedings of the National Academy of Sciences, India, 46, 694-698.

Hao, X., \& Papadopoulos, A. P. (2003). Effects of calcium and magnesium on growth, fruit yield and quality in fall greenhouse tomato crop grown on rockwool. Canadian Journal of Plant Science, 83, 903-912. https://doi.org/10.4141/P02-140

Hassan, N. K., Derwy, J. V., Mudren, K., Knadsin, D., \& Olseon, R. A. (1970). Influence of soil salinity on production of dry matter and uptake and distribution of nutrients in barley and corn. Agronomy Journal, 62, 43-45. https://doi.org/10.2134/agronj1970.00021962006200010014x

Jones, J. B. (1999). Tomato plant culture: In the field, greenhouse, and home garden. Florida, America: CRC Press LLC.

Jones, J. B. (2001). Laboratory guide for conducting soil tests and plant analysis. Washington, America: CRC Press.

Jones, J. B. (2003). Agronomic handbook: Management of crops, soils and their fertility. New York, America: CRC Press.

Kasiath, B. L., \& Senthikumar, M. (2015). Studies on intervention of potassium and magnesium nutrition and enhancing nutrient uptake and yield of tomato (Solanum lycopersicum L.). Plant Archives, 1, 357-362.

Kirkby, E. A., \& Mengel, K. (1976). The role of magnesium in plant nutrition. Journal of Plant Nutrition and Soil Science, 139, 209-222. https://doi.org/10.1002/jpln.19761390208

Majeed, A., Farrakh, M., \& Hussain, N. K. (2010). Effect of saline culture on the concentration of $\mathrm{Na}^{+}, \mathrm{K}^{+}$and $\mathrm{Cl}^{-}$in Agrostis tolonifera. Current Research Journal of Biological Sciences, 2, 76-82.

Maneenpong, S. (2008). A nutrient survey for establishment of standard recommendation of soil and plant analysis for pummelo. Agricultural Science Journal, 39, 62-65.

Maneepong, S. (2009). Nutrient requirement and fruit growth of pummelo. Agricultural Science Journal, 40, 412-415.

Maneepong, S. (2013). Nutrient management for high quality pummelo production (School of Agricultural Technology, Walailak University, Nakhon Si Thammarat, Thailand).

Nazanza, B. (2006). Yield and quality of tomato as influenced by differential $\mathrm{Ca}, \mathrm{Mg}$ and $\mathrm{K}$ nutrition (Unpublished master's thesis, Agricultural Science, University of Pretoria, South Africa).

Nguyen, H. H., Maneepong, S., \& Suraninpong, P. (2015). Behavior of nutrient uptake by pummelo growing on salt marsh soil. Proceedings of $2^{\text {nd }}$ International Symposium on Agricultural Technology (pp. 101-105). Pattaya, Thailand.

Nukaya, A., Goto, K., Jang, H., Kano, A., \& Ohkawa, K. (1995). Effect of $\mathrm{NH}_{4}-\mathrm{N}$ level in the nutrient solution on the incidence of blossom-end rot and gold specks on tomato fruit grown in rockwool. Acta Horticulturae, 401, 381-388. https://doi.org/10.17660/ActaHortic.1995.401.46

Pendias, A. K. (1992). Trace element in soil and plant. Boca Raton, Florida: CRC Press.

Prakash, R. P., Sushil, S. K., Viney, R. P., Vimal, J. P., \& Sunil, M. K. (2010). Impact of salt stress on nutrient uptake and growth of cowpea. Brazilian Society of Plant Physiology, 22, 43-48. https://doi.org/10.1590/ S1677-04202010000100005

Samarakoon, U. C., Weerasinghe, P. A., \& Weerakkody, W. A. P. (2006). Effect of electrical conductivity (EC) of nutrient solution on nutrient uptake, growth and yield of leaf lettuce. Tropical Agricultural Research, 18, 13-21.

Sayed, R. M. (2011). Zinc in crop production and interaction with phosphorus. Autralian Journal of Basic and Applied Science, 5, 1503-1509. 
Schimanski, C. (1981). The influence of certain experimental parameters on the flux characteristics of Mg-28 on case of barley seedlings grown in hydroculture. Schweiz. Landw. Forsch, 34, 154-165.

Shaw, R. J. (1999). Soil salinity—Electrical conductivity and chloride. In K. I. Peverill, L. A. Sparrow \& D. J. Reuter (Eds.), Soil analysis: An interpretation manual (pp. 129-144). Melboune: CSIRO Publishing.

Soil and Plant Analysis Council. (1998). Handbook of Reference Methods for Plant Analysis. Boca Raton, America: CRC Press.

Voogt, W. (1987). The growth of beefsteak tomato as affected by K/Ca ratios in the nutrient solution. Acta Horticulturae, 22, 155-165.

Yousufinia, M., Ghasemian, A., Safalian, O., \& Asadi, A. (2013). The effect of $\mathrm{NaCl}$ on the growth and $\mathrm{Na}^{+}$and $\mathrm{K}^{+}$content of barley (Hordeum vulgare L.) cultivares. Annals of Biological Research, 4, 80-85.

Zamaniyan, M., Panahandeh, J., Tabatabaei, S. J., \& Motallebie-Azar, A. (2012). Effects of different ratios of K: $\mathrm{Ca}$ in nutrient solution on growth, yield and chicon quality of witloof chicory (Cichorium intybus L.). International Journal of Agricultural Science, 2, 1137-1142.

Zhuang, Y., Renji, W., Lixuan, C., Zhian, X., Wenbao, X., Yuzong, H., \& Zhenlong, Z. (1991). Optimum range of mineral element contents in the leaves of Guanxi honey pomelo (Citrus grandis). Journal of Fujian Academy of Agricultural Sciences, 6(2), 52-58.

\section{Copyrights}

Copyright for this article is retained by the author(s), with first publication rights granted to the journal.

This is an open-access article distributed under the terms and conditions of the Creative Commons Attribution license (http://creativecommons.org/licenses/by/4.0/). 